Preliminary draft

Not for quotation nor citation

without an author's permission

\title{
EARNINGS AND OCCUPATIONAL ATTAINMENT: \\ IMMIGRANTS AND THE NATIVE BORN
}

\author{
By \\ Barry R. Chiswick \\ Department of Economics \\ University of Illinois at Chicago \\ $\&$ \\ IZA-Institute for the Study of Labor \\ and \\ Paul W. Miller \\ Business School \\ University of Western Australia
}

Keywords: Immigrants, Occupation, Earnings

JEL Codes: J240, J310, J 620, F22

* We thank Derby Voon for research assistance. Chiswick acknowledges research support from the Institute of Government and Public Affairs, University of Illinois. Miller acknowledges financial assistance from the Australian Research Council. 
March 2007

\title{
EARNINGS AND OCCUPATIONAL ATTAINMENT: IMMIGRANTS AND THE NATIVE BORN
}

\begin{abstract}
This paper examines the determinants of occupational attainment and the impact of occupation on earnings. Results for both the native born and foreign born are presented, and these provide insights as to the earnings penalties associated with the lessthan-perfect international transferability of human capital skills. It shows that around 50 percent of the earnings gains associated with years of schooling derives from interoccupational mobility. When occupation is held constant, there is a large increase in the effect on earnings of pre-immigration labor market experience for the foreign born, but little change in either the payoff to labor market experience for the native born, or in the premium for post-arrival labor market experience for the foreign born.

The estimates of the models of occupational attainment show that years of schooling, and, among the foreign born, proficiency in English, are the key factors determining access to high-paying occupations. Labor market experience has little effect on occupational outcomes among the native born. However, evaluated at 10 years, foreign labor market experience has a modest negative impact on current occupational status. Examination of this negative effect using quantile regression shows that is concentrated among those in high status jobs. (196 words)
\end{abstract}




\section{EARNINGS AND OCCUPATIONAL ATTAINMENT: IMMIGRANTS AND THE NATIVE BORN}

\section{INTRODUCTION}

Immigrants’ post-migration economic adjustment has typically been analyzed using an earnings function approach. In this approach, immigrants' earnings are related to their years of formal schooling, years of pre-immigration experience, years of postimmigration experience, and a range of demographic and region of residence control variables. A set of stylized facts has emerged from this line of research in the US and other destination countries, including (i) the payoff to immigrants' schooling is generally far less than the payoff obtained by the native born; (ii) pre-immigration labor market experience is associated with quite modest increases in immigrants' post-arrival earnings; (iii) years of post-arrival labor market experience among the foreign born are rewarded at a higher rate than years of pre-migration labor market experience; and (iv) destination language proficiency is an important determinant of immigrants' economic success.

Most researchers who study immigrants' earnings adjustment do not include variables for occupation of employment in the estimating equation. The main reason for this appears to be that occupation is typically viewed as a grouped variant of the dependent variable, and therefore it is not legitimate to use it as a regressor (Mincer (1979) as cited in Sloane (1985, p. 125)). Similarly, earnings and occupation may both be viewed as (imperfect) measures of the same unmeasurable variable of interest, labor market outcome.

Occupation of employment might be included in the model, however, where the aim is to inform on the channels through which earnings gains are achieved. Groshen (1991, p. 883), for example, argued that “...attributes of individuals (for example, race, education, marital status) must operate through occupation, employer, or job-cell in order for them to affect wages.” Earlier, Duncan (1961, pp.116-117) had noted “...a man qualifies himself for occupational life by obtaining an education; as a consequence of pursuing his occupation, he obtains income. Occupation, therefore, is the intervening activity linking income to education”. In other words, education or any other variable 
can be viewed as having both direct and indirect impacts on earnings, with the indirect impacts operating via occupational attainment. These issues, however, do not appear to have been systematically explored in the context of the determinants of immigrants' earnings.

This paper therefore has two aims. First, for immigrants in the US, earnings functions are estimated both with and without variables for occupation. For comparison purposes, earnings functions for the native born both with and without information on occupation are also presented. Alternative specifications are employed, where occupations are measured at different levels of aggregation. These results provide insights on the relative importance of the inter-occupational and intra-occupational channels of immigrants', compared to natives', economic progress. They show the potentially large, and intriguing, role that occupation apparently has in understanding variations in immigrants' earnings. This then provides the empirical basis for the second aim of the paper, namely to examine models of occupational attainment among immigrants and the native born.

The structure of this paper is as follows. Section II provides estimates of three specifications of an earnings function: one that does not include variables for occupation; a second that standardizes for occupation at the major group level, and a third that distinguishes among approximately 500 occupations. The results from this exercise appear to establish a clear case for the study of occupational attainment. Section III provides a brief review of the approaches that have been taken when modelling occupational attainment. Section IV presents estimates of several models of occupational attainment for the foreign born and the native born. These follow the literature and use mean earnings to rank occupations. Section $\mathrm{V}$ is the conclusion.

\section{EARNINGS AND OCCUPATIONS}

The analyses in this section are based on data for adult males (ages 25-64 years) from the 2000 U.S. Census one percent Public Use Microdata Sample. This sample provides details on earnings and work activity in 1999, together with information on a rich array of personal characteristics. Of specific note is that it codes the occupation in which the individual works in considerable detail. In particular, the 2000 Census 
occupational classification system consists of 509 specific categories for employed people that are structured into 23 major occupational groups. ${ }^{1}$

The typical human capital earnings function employed in the literature relates the natural logarithm of annual earnings to educational attainment (EDUC), measured by the years of full-time equivalent education, potential labor market experience, measured by age minus education minus six years, $(E X P)$, the natural logarithm of weeks worked (WEEKS), years since migration for the foreign born (YSM), and a set of dichotomous variables for foreign birth $(\mathrm{FOR}=1)$, race $(B L A C K=1)$, marital status $(M A R R I E D=1)$, location (METROPOLITAN AREA=1 and SOUTH=1), veteran status (VETERAN=1), and sometimes, for English language proficiency. The self-reported census information on English language proficiency allows five separate categories of skills to be identified, namely those who speak only English at home (speaking "English only”), which serves as the benchmark, and those who speak a language other than English at home and speak English "Very Well”, "Well”, “Not Well” or “Not at All”. For the native born, however, owing to the small numbers in the classifications of limited English skills, the categories of "Not Well" and "Not at All" are combined, whereas they are kept separate in the estimations for the foreign born. Both the potential labor market experience and years since migration variables are entered into the model in quadratic form. All variables are defined in Appendix A.

Estimates of earnings functions with and without controls for occupation are presented in Table 1 for the native born and Table 2 for the foreign born. Column (i) of each table lists results from a conventional model, and is presented to serve as a benchmark against which the impact of standardization for occupation can be assessed. Hence, they will not be discussed. Instead, the focus will be on the changes to the estimated coefficients as occupation is held constant, at two different levels of disaggregation.

${ }^{1}$ This classification was developed based on the Standard Occupational Classification (SOC) Manual: 2000, which comprises a hierarchical structure presenting 23 major occupational groups being divided into 96 minor groups, 449 broad groups, and 821 detailed occupations. Note that not all 821 detailed occupation titles are included in the Census classification, with many smaller detailed occupation titles being combined. 
Table 1

Estimates of Earnings Equations, Native Born Males, Age 25-64, 2000 (Dependent Variable: Natural Logarithm of Earnings)

\begin{tabular}{|c|c|c|c|c|c|}
\hline \multirow[b]{2}{*}{ Variable } & \multirow[b]{2}{*}{$\begin{array}{l}\text { Standard } \\
\text { Model } \\
\text { (i) }\end{array}$} & \multirow{2}{*}{$\begin{array}{c}\text { Model } \\
\text { with } 23 \\
\text { Occupation } \\
\text { Dummies } \\
\text { (ii) }\end{array}$} & \multirow{2}{*}{$\begin{array}{c}\text { Model } \\
\text { with } 509 \\
\text { Occupation } \\
\text { Dummies } \\
\text { (iii) }\end{array}$} & \multicolumn{2}{|c|}{$\begin{array}{l}\text { Percent Change from } \\
\text { Standard Model }^{(\mathrm{a})}\end{array}$} \\
\hline & & & & $\begin{array}{l}\text { Column } \\
\text { (ii) } \\
\text { Model }\end{array}$ & $\begin{array}{l}\text { Column } \\
\text { (iii) } \\
\text { Model }\end{array}$ \\
\hline Constant & $\begin{array}{c}4.347 \\
(193.00)\end{array}$ & - & - & - & - \\
\hline $\begin{array}{l}\text { Years of } \\
\text { Education }\end{array}$ & $\begin{array}{c}0.106 \\
(202.06)\end{array}$ & $\begin{array}{c}0.082 \\
(149.40)\end{array}$ & $\begin{array}{c}0.058 \\
(103.56)\end{array}$ & -22.6 & -45.3 \\
\hline Experience & $\begin{array}{c}0.033 \\
(71.94)\end{array}$ & $\begin{array}{c}0.033 \\
(76.61)\end{array}$ & $\begin{array}{c}0.032 \\
(76.36)\end{array}$ & 0.0 & -3.0 \\
\hline $\begin{array}{l}\text { Experience } \\
\text { Squared/100 }\end{array}$ & $\begin{array}{l}-0.057 \\
(55.56)\end{array}$ & $\begin{array}{l}-0.057 \\
(64.00)\end{array}$ & $\begin{array}{l}-0.055 \\
(63.64)\end{array}$ & 0.0 & -3.5 \\
\hline $\begin{array}{l}\text { Log Weeks } \\
\text { Worked }\end{array}$ & $\begin{array}{c}1.009 \\
(183.28)\end{array}$ & $\begin{array}{c}0.983 \\
(369.42)\end{array}$ & $\begin{array}{c}0.956 \\
(370.62)\end{array}$ & -2.6 & -5.3 \\
\hline Married & $\begin{array}{c}0.269 \\
(111.24)\end{array}$ & $\begin{array}{c}0.235 \\
(99.60)\end{array}$ & $\begin{array}{c}0.202 \\
(87.93)\end{array}$ & -12.6 & -24.9 \\
\hline South & $\begin{array}{l}-0.057 \\
(24.68)\end{array}$ & $\begin{array}{l}-0.065 \\
(28.61)\end{array}$ & $\begin{array}{l}-0.075 \\
(34.28)\end{array}$ & +14.0 & +31.6 \\
\hline $\begin{array}{l}\text { Metropolitan } \\
\text { Area }\end{array}$ & $\begin{array}{c}0.211 \\
(35.63)\end{array}$ & $\begin{array}{c}0.198 \\
(36.17)\end{array}$ & $\begin{array}{c}0.162 \\
(30.66)\end{array}$ & -6.2 & -23.2 \\
\hline Veteran & $\begin{array}{l}-0.046 \\
(16.95)\end{array}$ & $\begin{array}{l}-0.041 \\
(15.20)\end{array}$ & $\begin{array}{l}-0.046 \\
(17.59)\end{array}$ & -10.9 & 0.0 \\
\hline Blacks & $\begin{array}{l}-0.153 \\
(42.96)\end{array}$ & $\begin{array}{l}-0.102 \\
(27.85)\end{array}$ & $\begin{array}{l}-0.076 \\
(21.39)\end{array}$ & -33.3 & -50.3 \\
\hline $\begin{array}{l}\text { English Very } \\
\text { Well }\end{array}$ & $\begin{array}{c}-0.059 \\
(11.61)\end{array}$ & $\begin{array}{l}-0.046 \\
(9.29)\end{array}$ & $\begin{array}{l}-0.040 \\
(8.32)\end{array}$ & -22.0 & -32.2 \\
\hline English Well & $\begin{array}{l}-0.096 \\
(7.50)\end{array}$ & $\begin{array}{l}-0.087 \\
(7.18)\end{array}$ & $\begin{array}{l}-0.070 \\
(5.99)\end{array}$ & -9.4 & -27.1 \\
\hline $\begin{array}{l}\text { English Not } \\
\text { Well/Not at } \\
\text { All }\end{array}$ & $\begin{array}{l}0.012 \\
(0.65)\end{array}$ & $\begin{array}{l}0.015 \\
(0.88)\end{array}$ & $\begin{array}{l}0.009 \\
(0.55)\end{array}$ & +25.0 & -25.0 \\
\hline $\bar{R}^{2}$ & 0.335 & 0.367 & 0.412 & - & - \\
\hline Sample Size & 533,906 & 533,906 & 533,906 & - & - \\
\hline
\end{tabular}

Notes: ' $\mathrm{t}$ ' statistics in parentheses; $\mathrm{a}$ = changes computed with reference to absolute values of coefficients. Source: 2000 US Census 1\% PUMS. 
Table 2

Estimates of Earnings Equations, Foreign Born Males, Age 25-64, 2000 (Dependent Variable: Natural Logarithm of Earnings)

\begin{tabular}{|c|c|c|c|c|c|}
\hline \multirow[b]{2}{*}{ Variable } & \multirow[b]{2}{*}{$\begin{array}{c}\text { Standard } \\
\text { Model } \\
\text { (i) }\end{array}$} & \multirow{2}{*}{$\begin{array}{c}\text { Model } \\
\text { with } 23 \\
\text { Occupation } \\
\text { Dummies } \\
\text { (ii) }\end{array}$} & \multirow{2}{*}{$\begin{array}{c}\text { Model } \\
\text { with } 491 \\
\text { Occupation } \\
\text { Dummies } \\
\text { (iii) }\end{array}$} & \multicolumn{2}{|c|}{$\begin{array}{l}\text { Percent Change from } \\
\text { Standard Model }^{(a)}\end{array}$} \\
\hline & & & & $\begin{array}{l}\text { Column } \\
\text { (ii) } \\
\text { Model }\end{array}$ & $\begin{array}{l}\text { Column } \\
\text { (iii) } \\
\text { Model }\end{array}$ \\
\hline Constant & $\begin{array}{c}5.851 \\
(108.21)\end{array}$ & - & - & - & - \\
\hline $\begin{array}{l}\text { Years of } \\
\text { Education }\end{array}$ & $\begin{array}{c}0.053 \\
(69.16)\end{array}$ & $\begin{array}{c}0.032 \\
(40.31)\end{array}$ & $\begin{array}{c}0.023 \\
(28.66)\end{array}$ & -39.6 & -56.6 \\
\hline Experience & $\begin{array}{c}0.012 \\
(11.08)\end{array}$ & $\begin{array}{c}0.018 \\
(17.69)\end{array}$ & $\begin{array}{c}0.019 \\
(19.04)\end{array}$ & +50.0 & +58.3 \\
\hline $\begin{array}{l}\text { Experience } \\
\text { Squared/100 }\end{array}$ & $\begin{array}{l}-0.016 \\
(8.12)\end{array}$ & $\begin{array}{l}-0.028 \\
(14.90)\end{array}$ & $\begin{array}{l}-0.030 \\
(16.31)\end{array}$ & +75.0 & +87.5 \\
\hline $\begin{array}{l}\text { Years Since } \\
\text { Migration } \\
\text { (YSM) }\end{array}$ & $\begin{array}{c}0.011 \\
(13.00)\end{array}$ & $\begin{array}{c}0.012 \\
(15.30)\end{array}$ & $\begin{array}{c}0.012 \\
(15.38)\end{array}$ & +9.1 & +9.1 \\
\hline $\begin{array}{l}\text { YSM } \\
\text { Squared/100 }\end{array}$ & $\begin{array}{l}-0.011 \\
(5.55)\end{array}$ & $\begin{array}{l}-0.012 \\
(6.96)\end{array}$ & $\begin{array}{l}-0.014 \\
(7.97)\end{array}$ & +9.1 & +27.3 \\
\hline $\begin{array}{l}\text { Log Weeks } \\
\text { Worked }\end{array}$ & $\begin{array}{c}0.875 \\
(72.99)\end{array}$ & $\begin{array}{c}0.856 \\
(151.70)\end{array}$ & $\begin{array}{c}0.841 \\
(152.71)\end{array}$ & -2.2 & -3.9 \\
\hline Married & $\begin{array}{c}0.213 \\
(35.73)\end{array}$ & $\begin{array}{c}0.180 \\
(31.38)\end{array}$ & $\begin{array}{c}0.158 \\
(28.07)\end{array}$ & -15.5 & -25.8 \\
\hline South & $\begin{array}{l}-0.071 \\
(11.72)\end{array}$ & $\begin{array}{l}-0.085 \\
(14.48)\end{array}$ & $\begin{array}{l}-0.088 \\
(15.36)\end{array}$ & +19.7 & +23.9 \\
\hline $\begin{array}{l}\text { Metropolitan } \\
\text { Area }\end{array}$ & $\begin{array}{l}0.134 \\
(5.00)\end{array}$ & $\begin{array}{l}0.095 \\
(3.56)\end{array}$ & $\begin{array}{l}0.084 \\
(3.22)\end{array}$ & -29.1 & -37.3 \\
\hline Veteran & $\begin{array}{l}-0.084 \\
(6.52)\end{array}$ & $\begin{array}{r}-0.052 \\
(4.06)\end{array}$ & $\begin{array}{r}-0.046 \\
(3.69)\end{array}$ & -38.1 & -45.2 \\
\hline Blacks & $\begin{array}{l}-0.184 \\
(17.17)\end{array}$ & $\begin{array}{l}-0.110 \\
(10.52)\end{array}$ & $\begin{array}{l}-0.067 \\
(6.51)\end{array}$ & -40.2 & -63.6 \\
\hline $\begin{array}{l}\text { English } \\
\text { Very Well }\end{array}$ & $\begin{array}{c}-0.080 \\
(8.55)\end{array}$ & $\begin{array}{l}-0.071 \\
(8.52)\end{array}$ & $\begin{array}{l}-0.057 \\
(6.95)\end{array}$ & -11.3 & -28.8 \\
\hline $\begin{array}{l}\text { English } \\
\text { Well }\end{array}$ & $\begin{array}{l}-0.261 \\
(26.19)\end{array}$ & $\begin{array}{l}-0.177 \\
(19.49)\end{array}$ & $\begin{array}{l}-0.134 \\
(15.06)\end{array}$ & -32.2 & -48.7 \\
\hline $\begin{array}{l}\text { English Not } \\
\text { Well }\end{array}$ & $\begin{array}{c}-0.373 \\
(33.93)\end{array}$ & $\begin{array}{c}-0.269 \\
(26.57)\end{array}$ & $\begin{array}{l}-0.217 \\
(21.80)\end{array}$ & -27.9 & -41.8 \\
\hline $\begin{array}{l}\text { English Not } \\
\text { at All }\end{array}$ & $\begin{array}{l}-0.378 \\
(27.46)\end{array}$ & $\begin{array}{l}-0.300 \\
(22.50)\end{array}$ & $\begin{array}{l}-0.252 \\
(19.23)\end{array}$ & -20.6 & -33.3 \\
\hline $\bar{R}^{2}$ & 0.363 & 0.415 & 0.449 & - & - \\
\hline Sample Size & 84,290 & 84,290 & 84,290 & - & - \\
\hline
\end{tabular}

Notes: 't' statistics in parentheses; a = changes computed with reference to absolute values of coefficients. Source: 2000 US Census 1\% PUMS. 
Column (ii) of Tables 1 and 2 contains the results when separate intercept terms are included in the model for each of 23 major group occupations. As this set of occupational dichotomous variables holds constant the inter-occupation earnings structure, the coefficients on other variables (e.g., schooling, experience) record their impacts on intraoccupational earnings mobility. Following standardization for the occupational earnings structure at the major-group level, the payoff to schooling for the native born decreases from 10.6 percent to 8.2 percent, a 23 percent reduction. For the foreign born, following the control for occupation fixed effects (at the major group level) the payoff to schooling also decreases, although the reduction is considerably greater than for the native born. Thus, the payoff to schooling for the foreign born falls from 5.3 percent to 3.2 percent, a 40 percent change. In other words, among the native born and foreign born, about 23 percent and 40 percent, respectively, of the increase in earnings associated with additional years of schooling occurs through entrance into higher-paying occupations, as broadly defined here. The remaining part of the payoff to schooling is associated with higher earnings within the major group occupations.

In stark contrast to the situation with formal schooling, however, once occupation of employment is held constant, the payoff to experience for the native born does not change. In both the conventional earnings function and when the major group occupation is held constant, the payoff to experience for the native born is 2.2 percent at 10 years of experience, and 1.0 percent at 20 years of experience. These and other payoffs are summarized in Table 3. This suggests that earnings mobility with labor market experience among the native born is achieved through upward earnings mobility within an occupation rather than via movement across the major group occupations. An implication of this result is that occupational outcome - at the major group level - is on the basis of pre-labor market characteristics, such as the highest educational level attained. This is an intuitively reasonable implication.

Among the native born, speaking a language other than English at home is associated with lower earnings, 6 percent lower earnings if English is spoken "very well” and 10 percent lower earnings if English is spoken "well". ${ }^{2}$ The negative effect becomes

\footnotetext{
${ }^{2}$ This is consistent with the findings in Chiswick and Miller (1998).
} 
smaller in absolute magnitude when occupation is held constant. These effects imply that some of the earnings gain to the native born from greater proficiency ( 9 to 32 percent) is due to placement in higher paying occupations, but much of it arises from intraoccupational earnings mobility.

Table 3

Payoffs to Educational Attainment and Labor Market Experience from Analysis of Earnings, Native Born Males, Age 25-64, 2000

\begin{tabular}{|c|c|c|c|c|c|}
\hline \multirow[b]{2}{*}{ Variable } & \multicolumn{3}{|c|}{ Payoffs from Earnings Function } & \multicolumn{2}{|c|}{ \% Change } \\
\hline & Standard & $\begin{array}{c}\text { Controlling } \\
\text { for } 23 \\
\text { Occupations } \\
\end{array}$ & $\begin{array}{c}\text { Controlling } \\
\text { for } 509 \\
\text { Occupations }\end{array}$ & $\begin{array}{c}\text { With } 23 \\
\text { Occupations }\end{array}$ & $\begin{array}{c}\text { With } 509 \\
\text { Occupations }\end{array}$ \\
\hline $\begin{array}{l}\text { Educational } \\
\text { Attainment }\end{array}$ & 10.6 & 8.2 & 5.8 & -23 & -45 \\
\hline $\begin{array}{l}\text { Labor } \\
\text { Market } \\
\text { Experience }\end{array}$ & & & & & \\
\hline $\begin{array}{l}-10 \text { years } \\
-20 \text { years }\end{array}$ & $\begin{array}{l}2.16 \\
1.02\end{array}$ & $\begin{array}{l}2.16 \\
1.02\end{array}$ & $\begin{array}{l}2.10 \\
1.00\end{array}$ & $\begin{array}{l}0 \\
0\end{array}$ & $\begin{array}{l}-3 \\
-2\end{array}$ \\
\hline
\end{tabular}

Source: Authors’ calculations based on Table 1 results.

In the case of the foreign born, however, the payoff to pre-immigration experience (i.e., experience controlling for years since migration) actually increases compared to that obtained with the conventional model that eschews information on occupation. Payoffs evaluated at 10 and 20 years of pre-immigration experience are presented in Table 4. These reveal that, following standardization for occupation, the payoff to preimmigration experience increases by around 40 percent at 10 years of experience, and by 20 percent at 20 years of experience. In other words, pre-immigration experience must be associated with immigrants being channelled in the destination into relatively low paying occupations. This appears to be a major result of the less-than-perfect international transferability of skills acquired on the job in the country of origin (see Chiswick, 1978).

When the relationship between earnings and years since migration is considered, it is apparent that controlling for the inter-occupational earnings structure has minimal impact on the estimates (see, in particular, the summary in Table 4). This is very similar 
to the finding in relation to labor market experience for the native born. In other words, the earnings growth that immigrants and the native born achieve as a result of U.S. labor market experience comes about through intra-occupation earnings mobility.

Table 4

Payoffs to Educational Attainment, Pre-Immigration Labor Market Experience and Duration of Residence from Analysis of Earnings, Foreign Born Males, Age 25-64, 2000

\begin{tabular}{|c|c|c|c|c|c|}
\hline \multirow[b]{2}{*}{ Variable } & \multicolumn{3}{|c|}{ Payoffs from Earnings Function } & \multicolumn{2}{|c|}{ \% Change } \\
\hline & Standard & $\begin{array}{c}\text { Controlling } \\
\text { for } 23 \\
\text { Occupations } \\
\end{array}$ & $\begin{array}{c}\text { Controlling } \\
\text { for } 491 \\
\text { Occupations }\end{array}$ & $\begin{array}{c}\text { With } 23 \\
\text { Occupations }\end{array}$ & $\begin{array}{c}\text { With } 491 \\
\text { Occupations }\end{array}$ \\
\hline $\begin{array}{l}\text { Educational } \\
\text { Attainment }\end{array}$ & 5.3 & 3.2 & 2.3 & -40 & -57 \\
\hline $\begin{array}{l}\text { Pre- } \\
\text { Immigration } \\
\text { Experience }\end{array}$ & & & & & \\
\hline $\begin{array}{l}\text { - } 10 \text { years } \\
\text { - } 20 \text { years }\end{array}$ & $\begin{array}{l}0.88 \\
0.56\end{array}$ & $\begin{array}{l}1.24 \\
0.68\end{array}$ & $\begin{array}{l}1.30 \\
0.70\end{array}$ & $\begin{array}{l}+41 \\
+21\end{array}$ & $\begin{array}{l}+48 \\
+25\end{array}$ \\
\hline $\begin{array}{l}\text { Years Since } \\
\text { Migration }\end{array}$ & & & & & \\
\hline $\begin{array}{l}-10 \text { years } \\
-20 \text { years }\end{array}$ & $\begin{array}{l}0.88 \\
0.66\end{array}$ & $\begin{array}{l}0.96 \\
0.72\end{array}$ & $\begin{array}{l}0.92 \\
0.64\end{array}$ & $\begin{array}{l}+9 \\
+9\end{array}$ & $\begin{array}{l}+5 \\
-3\end{array}$ \\
\hline
\end{tabular}

Source: Authors' calculations based on Table 2 results.

The estimated effects of English proficiency on earnings are also affected by the statistical control for occupation. For example, among the foreign born, the estimated effect in the standard earnings function of speaking a language other than English at home and speaking English "Very Well” is 8 percent lower earnings compared to English only speakers. This hardly changes (an increase of only one percentage point to 7 percent lower earnings) when account is taken of the major occupational groups. The changes in estimated impacts are more pronounced for the poorer English proficiency groups, with the largest change following standardization for occupation being the improvement from -0.373 to -0.269 in the estimated coefficient for the "English Not Well” variable. Thus, some of the earnings disadvantage of immigrants with limited English language proficiency is due to this deficiency placing them in lower earnings occupations. 
The patterns of change to the remaining estimated coefficients in the earnings equation following the standardization for occupation are similar for the two birthplace groups. Hence, there is little change in the estimated elasticity of earnings with respect to weeks worked, a reduction of 13 to 16 percent in the estimated marriage premium, an increase of 14 to 20 percent in the earnings penalty associated with residence in the South, and a large fall (of between 33 to 40 percent) in the earnings penalty associated with a Black racial origin. The changes to the coefficients for residence in the metropolitan areas and veteran status are in the same direction for the native born and the foreign born, but the changes are much more pronounced for the foreign born.

The inclusion of more detailed information on occupation in column (iii) of Tables 1 and 2 reinforces these key results. ${ }^{3}$ Hence, when the inter-occupational earnings structure is held constant at this more detailed level, the payoff to schooling (achieved through intra-occupational earnings mobility) for the native born falls, to a little more than one-half of that reported in the absence of controls for occupation. For the foreign born, the payoff to schooling achieved through intra-occupational earnings mobility is only around two-fifths of that reported in the conventional earnings equation that combines both inter-occupational and intra-occupational earnings effects. The payoff to pre-immigration labor market experience among the foreign born increases, by between 50 and 70 percent of the payoffs reported for the conventional earnings function. The payoffs to labor market experience for the native born and to years of residence in the US for the foreign born are virtually unaffected by the degree of detail on occupation used in the analysis. The estimated effects on earnings of English proficiency for both birthplace groups are reduced even further with the more detailed occupational classification. These range between 30 and 50 percent less (in absolute value) in the model with the larger number of occupations than when occupation is not included in the earnings function.

These results present a conundrum. Labor market experience among native-born males aged 25 to 64 in the US labor market does not, from this study of earnings, appear to be associated with mobility to higher paying occupations. Yet the foreign born with

\footnotetext{
${ }^{3}$ The number of intercept terms for the foreign born is less than the 509 occupation groups recorded in the Census owing to the omission of several where adult, foreign-born males were not represented in the sample.
} 
labor market experience are being assigned to lower-ranked occupations. One possibility is that this is a reflection of a matching process in the labor market, where education and other, essentially pre-labor-market-entry, characteristics determine occupation. Provided their education is of a recent vintage, an immigrant will get access to an appropriate occupation. But if the education is of an older vintage, the immigrant gets assigned to a lesser job, possibly because it is more difficult for employers to assess how relevant the immigrant's skills are to the current labor market, or because these generalized skills become more country-specific with longer work experience in the origin. It is noted that the same phenomenon appears to occur in relation to the earnings of women. Miller (1987), for example, estimated an ordered probit model of occupational attainment for married women (albeit with only six separate occupations) and reported that labor market experience was linked to employment in occupations with lower mean earnings. This was shown to be a result of a negative relationship between time spent out of the labor market and occupational prestige after returning to employment. Time spent out of the destination labor market, as measured by pre-immigration experience, may have a similar effect.

Clearly, occupation plays a key role in determining the earnings outcomes for both immigrants and the native born. It seems important, therefore, to attempt to understand this directly through analysis of models of occupational attainment, rather than inferring patterns from the extended earnings functions considered in Tables 1 and 2. These matters are addressed in the remainder of this paper.

\section{MODELLING OCCUPATIONAL OUTCOMES}

Studies of occupational outcomes have usually been based on a general model as follows:

$$
Y_{i}=\alpha+X_{i}^{\prime} \beta+\varepsilon_{i}
$$

where $Y$ is a continuous variable which records the perceived "goodness of an occupation”, $X$ is a set of attributes of workers thought likely to impact on occupational outcomes, and $\varepsilon$ is a stochastic disturbance term.

Studies of this genre generally proceed in either of two main ways. In the first of these, typified by the work of Brown et al. (1980a)(1980b), Miller and Volker (1985), 
and Kidd and Shannon (1996), the likelihood of working in a number of occupational categories is examined using probability models. The basis of these models is the argument that $Y$, the perceived "goodness of an occupation”, is unobserved. Instead, what is usually analyzed is discrete data on occupation type. These data take the form of a variable $O_{i}=1,2, \ldots, j$, where $O_{i}=j$ if the individual works in the $j$ th occupation. These studies then examine the determinants of the conditional probability that an individual $i$ works in occupation $h$ as:

$$
P_{i h} \mid X_{i}=f\left(X_{i}\right)
$$

When occupational outcomes have been examined from this discrete choice perspective, the main method of estimation has been the multinomial logit model. With this model the discrete response variable consists of a set of mutually exclusive and exhaustive occupation categories that can be ranked arbitrarily without any effect on the value of the estimated parameters. Under this approach, the conditional probability that individual $i$ ends up in occupation $h$ is given as (see Schmidt and Strauss, 1975; Brown et al., 1980; and Polachek, 1981):

$$
P_{i h} \mid X_{i}=\frac{e^{X_{i}^{\prime} \beta_{h}}}{\sum_{k=1}^{j} e^{X_{i}^{\prime} \beta_{k}}}
$$

The problem with this approach is that the large number of categories makes interpretation difficult.

An alternative probability model that has been used is the ordered probit model, which is to be preferred in this analysis. This model is similar to that of the unordered models in providing a prediction of the conditional probability that individual $i$ ends up in occupation $h$, although it presumes that the occupational categories can be suitably ranked (see McKelvey and Zavoina, 1975; Miller and Volker, 1985). Accordingly, the $j$ occupations are ranked from lowest to highest, using an underlying scale of measurement. These observed occupational categories are then linked to the unobserved underlying index of the "goodness" of the occupation ( $Y$ in equation (1)) as follows: 


$$
\begin{array}{cl}
O_{i}=1 & \text { if } Y_{i}<\mu_{1} \\
O_{i}=2 & \text { if } \mu_{1} \leq Y_{i}<\mu_{2} \\
O_{i}=3 & \text { if } \mu_{2} \leq Y_{i}<\mu_{3} \\
& \vdots \\
O_{i}=j & \text { if } \mu_{j-1}<Y_{i}
\end{array}
$$

where the $\mu \mathrm{s}$ are unknown threshold parameters separating the adjacent occupational categories. These can be estimated together with the $\beta$ in the index specified in equation (1). With the normal distribution, the conditional probability of individual $i$ being in occupation $h$ can be calculated as:

$$
P_{i h} \mid X_{i}=\Phi\left(\mu_{h}-X_{i}^{\prime} \beta\right)-\Phi\left(\mu_{h-1}-X_{i}^{\prime} \beta\right)
$$

Various alternatives have been proposed for ranking occupations. For example, Miller and Volker (1985) use both status-attainment scores and income to establish rankings among occupations in their empirical analyzes and find marked differences between the estimated probabilities based on these two alternative rankings. However, they contend that no one ordering scheme is necessarily superior, and recommend analysis with several ordering variables.

The alternative approach to modelling occupational outcome is to focus on occupational attainment models, estimated using Ordinary Least Squares. Examples of this approach are Nickell (1982), Evans (1987), Evans and Kelley (1986) and Polachek (1981). Polachek (1981) characterizes occupations by their atrophy rates, that is, the rate at which earnings decreases with absence from the labor market. He uses the occupation atrophy rates as the dependent variables in a model of occupational choice. Evans (1987) and Evans and Kelley (1986) measure occupational attainment in Australia using a status attainment score, specifically the ANU2 occupational status scores. This scale is based on prestige ratings, and provides a link between census occupational classifications and popular ratings of the social standing of jobs (Jones, 1989). On the other hand, Nickell (1982) measures success using the average hourly earnings within each occupation. An argument in favor of the use of mean earnings over a status attainment scale is that changes in earnings are amenable to a clear, quantitative scale. An argument in favor of 
the use of a status attainment scale is that it is more encompassing than the simple monetary magnitude provided by mean occupational earnings. Duncan (1961), for example, discusses education as an indicator of social status and income as a measure of economic status, and the socioeconomic index as reflecting both of these. However, Nickell (1982) reports a correlation of 0.85 between his hourly income variable and a status ranking variable ${ }^{4}$, which suggests that similar findings should be derived from the study of these alternative measures of the goodness of occupations within a linear regression framework.,

The relative merits of the probability and occupational attainment models cannot be evaluated formally (i.e., in a statistical sense). In this situation, an expedient way of proceeding is to tailor the method to the specific issue that is to be addressed. In this particular instance, the main research question is the role of the worker's characteristics in getting them access to better jobs. From this perspective, following the status attainment literature has merit. ${ }^{7}$ Within this framework, the approach of Nickell (1982) is followed, and mean occupational earnings are used to rank occupations.

Hence, the analysis proposed is the estimation of a status attainment model:

$$
\text { Occ }_{i}=\alpha X_{i}+v_{i}
$$

where $\mathrm{Occ}_{i}$ is the mean occupational earnings of the Census occupational category (around 500 specific occupations) in which individual $i$ works, $X_{i}$ is a set of the

\footnotetext{
${ }^{4}$ The definition of status ranking is derived by Goldthorpe and Hope (1974) based on respondents' rankings of occupations according to general standing or prestige.

${ }^{5}$ Nickell (1982) thus contends that occupational success is simply reflecting a relatively high average hourly earnings in an occupation.

${ }^{6}$ Leigh (1976) examines occupational change over a five-year period, 1965 to 1970, using a variant of the above approach. In Leigh's (1976) study the change in median occupational earnings (measured at the three-digit level) is used to determine whether occupational change is upward, lateral or downward.

${ }^{7}$ This appears to be consistent with Duncan's (1961, p. 139) comment that "There can be no such thing as a single index of socioeconomic status for all purposes of social research...Given the actual complexity and multidimensionality of the stratification structure, any particular variable or index can at best reflect a selected aspect of the structure that may be strategic from a certain point of view”.
} 
individual's attributes that influences this occupational outcome, and $v_{i}$ is a random error term. As a check on the robustness of the empirical findings, ordered probit models are also estimated using mean occupational earnings as the ranking instrument, but with the more limited number of occupations - 23 - provided by the Census major occupational groups.

\section{ESTIMATES OF MODELS OF OCCUPATIONAL ATTAINMENT}

This section presents estimates of several variants of the model of occupational attainment set out in equation (6).

\section{A. OLS and Ordered Probit Analysis of Occupational Attainment}

Results are presented in Table 5 for the native born and in Table 6 for the foreign born. These results refer to a model of occupational attainment, estimated by Ordinary Least Squares, and using the unit level occupation data for about 500 occupations (columns (i) and (ii) of each table), and a probability model of occupational outcomes estimated using an ordered probit model, based on only the 23 major group occupations (columns (iii) and (iv) of each table). The estimated separation points (i.e., the $\hat{\mu} \mathrm{s}$ ) for the ordered probit model are not listed: these are available from the authors upon request.

Two specifications of the estimating equation are presented under each approach. The first does not contain variables for English language proficiency, while the second does. While there are reasonably large numbers in the various English proficiency categories for the foreign born, this is not the case for the native born. Among the native born there are limited numbers in the English skills categories other than the "Very Well" group, and the meaning of reporting speaking English in the "Well", "Not Well" and "Not at All” categories for the native born is not at all clear. Chiswick and Miller (1998), for example, argue that the native born who report that they are bilingual and speak English "Very Well” may have lesser proficiency in English than monolingual English speakers because speaking in childhood and/or as adults this other language competes with their obtaining full proficiency in English. Chiswick and Miller (1998) also argue that this small group of the native born may experience discrimination because of an accent or speech pattern related to their other language. Finally, it has been advanced that living and working in an ethnic concentration area because of their language deficiencies 
may also impact on their labor market outcome. Yet, it is unclear why there would be adult men born in the US who report their English-speaking proficiency as less than "Very Well”.

The pattern of effects in the OLS models of occupational status is remarkably the same as that in the ordered probit models. For brevity, only the OLS results will be discussed. $^{8}$

Table 5

Estimates of Models of Occupational Attainment (Ranked by Mean Occupational Earnings), Native Born Males, Age 25-64, 2000 (Dependent Variable: Mean Occupational Natural Logarithm of Annual Earnings)

\begin{tabular}{lcccc}
\hline & $\begin{array}{c}\text { OLS-without } \\
\text { English } \\
\text { Variables }\end{array}$ & $\begin{array}{c}\text { OLS-with } \\
\text { English } \\
\text { Variables } \\
\text { Variable }\end{array}$ & $\begin{array}{c}\text { Ordered } \\
\text { Probit-without } \\
\text { English } \\
\text { Variables } \\
\text { (iii) }\end{array}$ & $\begin{array}{c}\text { Ordered } \\
\text { Probit-with } \\
\text { English } \\
\text { Variables } \\
\text { (iv) }\end{array}$ \\
\hline Constant & 8.754 & 8.759 & -1.267 & -1.262 \\
Years of & $(1223.98)$ & $(1221.85)$ & $(73.58)$ & $(73.11)$ \\
Education & 0.083 & 0.083 & 0.209 & 0.209 \\
Experience & $(312.62)$ & $(311.98)$ & $(358.19)$ & $(357.54)$ \\
& 0.001 & 0.001 & -0.009 & -0.009 \\
Experience & $(2.56)$ & $(2.28)$ & $(15.74)$ & $(15.86)$ \\
Squared/100 & 0.002 & 0.002 & 0.025 & 0.025 \\
Log Weeks & $(4.15)$ & $(4.31)$ & $(21.50)$ & $(21.56)$ \\
Worked & 0.088 & 0.088 & 0.157 & 0.157 \\
Married & $(62.26)$ & $(62.02)$ & $(45.97)$ & $(45.85)$ \\
South & 0.103 & 0.102 & 0.179 & 0.179 \\
& $(89.28))$ & $(88.98)$ & $(59.17)$ & $(59.03)$ \\
Metropolitan & 0.026 & 0.026 & 0.051 & 0.051 \\
Area & $(23.62)$ & $(23.72)$ & $(17.47)$ & $(17.50)$ \\
Veteran & 0.065 & 0.065 & 0.095 & 0.095 \\
Blacks & $(24.16)$ & $(24.36)$ & $(13.44)$ & $(13.53)$ \\
English Very & -0.009 & -0.009 & -0.055 & -0.055 \\
Well & $(7.50)$ & $(7.43)$ & $(16.22)$ & $(16.17)$ \\
English Well & -0.115 & -0.116 & -0.275 & -0.276 \\
& $(67.47)$ & $(67.91)$ & $(58.87)$ & $(59.03)$ \\
& $(a)$ & -0.023 & $(a)$ & -0.034 \\
& $(a)$ & $(9.34)$ & & $(5.31)$ \\
& & -0.030 & $(a)$ & -0.007 \\
& & $(4.95)$ & & $(0.44)$ \\
\hline
\end{tabular}

${ }^{8}$ The results for the weeks worked, marital status, location, veteran status and race variables accord with expectations, and do not warrant comment. 


\begin{tabular}{|c|c|c|c|c|}
\hline $\begin{array}{l}\text { English Not } \\
\text { Well/Not at } \\
\text { All }\end{array}$ & (a) & $\begin{array}{l}0.015 \\
(1.67)\end{array}$ & (a) & $\begin{array}{l}0.048 \\
(2.17)\end{array}$ \\
\hline $\bar{R}^{2}$ & 0.271 & 0.271 & - & - \\
\hline$\chi^{2}$ & - & - & 127556.4 & 127589.8 \\
\hline Sample Size & 533,906 & 533,906 & 533,906 & 533,906 \\
\hline \multicolumn{5}{|c|}{$\begin{array}{l}\text { Notes: ‘t' statistics in parentheses. } \\
\text { (a) Variable not entered. } \\
\text { Source: } 2000 \text { US Census 1\% PUMS. }\end{array}$} \\
\hline \multicolumn{5}{|c|}{$\begin{array}{c}\text { Table } 6 \\
\text { Estimates of Models of Occupational Attainment (Ranked by Mean Occupational } \\
\text { Earnings), Foreign Born Males, Age 25-64, } 2000 \\
\text { (Dependent Variable: Mean Occupational Natural Logarithm of Annual Earnings }\end{array}$} \\
\hline Variable & $\begin{array}{l}\text { OLS-without } \\
\text { English } \\
\text { Variables } \\
\text { (i) }\end{array}$ & $\begin{array}{l}\text { OLS-with } \\
\text { English } \\
\text { Variables } \\
\text { (ii) }\end{array}$ & $\begin{array}{c}\text { Ordered } \\
\text { Probit-without } \\
\text { English } \\
\text { Variables } \\
\text { (iii) }\end{array}$ & $\begin{array}{l}\text { Ordered } \\
\text { Probit-with } \\
\text { English } \\
\text { Variables } \\
\text { (iv) }\end{array}$ \\
\hline Constant & $\begin{array}{c}9.138 \\
(501.24)\end{array}$ & $\begin{array}{c}9.356 \\
(506.09)\end{array}$ & $\begin{array}{l}0.132 \\
(2.76)\end{array}$ & $\begin{array}{c}0.600 \\
(12.14)\end{array}$ \\
\hline $\begin{array}{l}\text { Years of } \\
\text { Education }\end{array}$ & $\begin{array}{c}0.055 \\
(152.23)\end{array}$ & $\begin{array}{c}0.048 \\
(125.74)\end{array}$ & $\begin{array}{c}0.131 \\
(153.75)\end{array}$ & $\begin{array}{c}0.117 \\
(125.79)\end{array}$ \\
\hline Experience & $\begin{array}{l}-0.011 \\
(20.50)\end{array}$ & $\begin{array}{l}-0.008 \\
(15.34)\end{array}$ & $\begin{array}{l}-0.032 \\
(24.16)\end{array}$ & $\begin{array}{l}-0.026 \\
(19.58)\end{array}$ \\
\hline $\begin{array}{l}\text { Experience } \\
\text { Squared/100 }\end{array}$ & $\begin{array}{c}0.022 \\
(22.11)\end{array}$ & $\begin{array}{c}0.018 \\
(18.96)\end{array}$ & $\begin{array}{c}0.061 \\
(24.51)\end{array}$ & $\begin{array}{c}0.055 \\
(21.96)\end{array}$ \\
\hline $\begin{array}{l}\text { Years Since } \\
\text { Migration } \\
\text { (YSM) }\end{array}$ & $\begin{array}{l}0.003 \\
(6.58)\end{array}$ & $\begin{array}{l}0.001 \\
(1.24)\end{array}$ & $\begin{array}{l}0.005 \\
(5.03)\end{array}$ & $\begin{array}{l}-0.000 \\
(0.37)\end{array}$ \\
\hline $\begin{array}{l}\text { YSM } \\
\text { Squared/100 }\end{array}$ & $\begin{array}{l}0.002 \\
(2.20)\end{array}$ & $\begin{array}{l}0.001 \\
(1.44)\end{array}$ & $\begin{array}{l}0.001 \\
(0.34)\end{array}$ & $\begin{array}{l}0.001 \\
(0.25)\end{array}$ \\
\hline $\begin{array}{l}\text { Log Weeks } \\
\text { Worked }\end{array}$ & $\begin{array}{c}0.066 \\
(22.35)\end{array}$ & $\begin{array}{c}0.059 \\
(20.47)\end{array}$ & $\begin{array}{c}0.104 \\
(13.92)\end{array}$ & $\begin{array}{c}0.091 \\
(12.07)\end{array}$ \\
\hline Married & $\begin{array}{c}0.081 \\
(27.15)\end{array}$ & $\begin{array}{c}0.079 \\
(26.98)\end{array}$ & $\begin{array}{c}0.136 \\
(17.87)\end{array}$ & $\begin{array}{c}0.132 \\
(17.32)\end{array}$ \\
\hline South & $\begin{array}{l}0.017 \\
(5.60)\end{array}$ & $\begin{array}{l}0.017 \\
(5.50)\end{array}$ & $\begin{array}{l}0.050 \\
(6.39)\end{array}$ & $\begin{array}{l}0.049 \\
(6.29)\end{array}$ \\
\hline $\begin{array}{l}\text { Metropolitan } \\
\text { Area }\end{array}$ & $\begin{array}{l}0.090 \\
(6.90)\end{array}$ & $\begin{array}{l}0.098 \\
(7.82)\end{array}$ & $\begin{array}{l}0.328 \\
(9.16)\end{array}$ & $\begin{array}{l}0.348 \\
(9.73)\end{array}$ \\
\hline Veteran & $\begin{array}{l}-0.017 \\
(2.60)\end{array}$ & $\begin{array}{l}-0.036 \\
(5.49)\end{array}$ & $\begin{array}{l}0.002 \\
(0.12)\end{array}$ & $\begin{array}{l}-0.039 \\
(2.33)\end{array}$ \\
\hline Blacks & $\begin{array}{l}-0.081 \\
(15.92)\end{array}$ & $\begin{array}{l}-0.138 \\
(25.75)\end{array}$ & $\begin{array}{l}-0.100 \\
(7.53)\end{array}$ & $\begin{array}{l}-0.221 \\
(16.12)\end{array}$ \\
\hline
\end{tabular}




\begin{tabular}{|c|c|c|c|c|}
\hline $\begin{array}{l}\text { English Very } \\
\text { Well }\end{array}$ & (a) & $\begin{array}{l}-0.027 \\
(5.79)\end{array}$ & (a) & $\begin{array}{l}-0.027 \\
(2.47)\end{array}$ \\
\hline English Well & (a) & $\begin{array}{c}-0.172 \\
(34.99)\end{array}$ & (a) & $\begin{array}{l}-0.352 \\
(29.38)\end{array}$ \\
\hline $\begin{array}{l}\text { English Not } \\
\text { Well }\end{array}$ & (a) & $\begin{array}{l}-0.235 \\
(45.60)\end{array}$ & (a) & $\begin{array}{c}-0.495 \\
(37.21)\end{array}$ \\
\hline $\begin{array}{l}\text { English Not at } \\
\text { All }\end{array}$ & (a) & $\begin{array}{l}-0.214 \\
(33.55)\end{array}$ & (a) & $\begin{array}{c}-0.479 \\
(27.06)\end{array}$ \\
\hline $\bar{R}^{2}$ & 0.324 & 0.350 & - & - \\
\hline$\chi^{2}$ & - & - & 28957.58 & 31410.72 \\
\hline Sample Size & 84,290 & 84,290 & 84,290 & 84,290 \\
\hline
\end{tabular}

Notes: ' $t$ ' statistics in parentheses.

(a) Variable not entered.

Source: 2000 US Census 1\% PUMS.

Given the use of the geometric mean of earnings (i.e., the mean of the logarithm of earnings) in the occupation as the dependent variable in the occupational attainment model of columns (i) and (ii) in Tables 5 and 6, these results can be viewed as providing estimates of the determinants of inter-occupational earnings differentials.

The first point of note is that the payoff to years of education in column (ii) in Tables 5 and 6 is 8.3 percent for the native born, and 4.8 percent for the foreign born. The elasticity of individual earnings - the dependent variable in Tables 1 and 2 - with respect to the mean occupational earnings used as the dependent variable in Tables 5 and 6 is 0.76 for the native born, and 0.72 for the foreign born. ${ }^{9}$ Hence, these estimates of the payoffs to years of education are consistent with the findings of Tables 1 and 2, to the effect that about one-half of the growth in individual earnings associated with years of education comes about through access to higher paying occupations, although this proportion is around 10 percentage points higher for the foreign born than for the native born.

The second feature of the Table 3 results is that there is a slight, positive relationship between occupational status and potential labor market experience for the native born, but a negative relationship between occupational status and pre-immigration experience (total experience when duration in the U.S. is held constant), up to 22 years of experience, for the foreign born. In other words, in terms of occupational attainment it is

${ }^{9}$ These elasticities are derived from the human capital earnings functions presented in Tables 1 and 2 augmented with a variable for the mean occupational earnings. 
better not to have worked abroad, but rather to have immigrated upon leaving school, than to have even a modest amount of foreign labor market experience.

Foreign work experience is typically associated with modest gains in post-arrival earnings in the study of individual earnings among the foreign born in the US. This is certainly the case in the results presented in Table 2 above. Hence, the Table 6 findings suggest that these earnings gains come about through achieving relatively high wages within occupations. In other words, a foreign-born worker with experience tends to be channelled into a lower-paying occupation (captured by mean occupational earnings), but within that occupation receives a relatively high rate of pay (captured in analyzes of individual earnings). It comes as no surprise that this is exactly the pattern of effects discussed in relation to the study of variation in individual earnings with experience following the inclusion of variables for occupation of employment in Table 2.

Similarly, there are only modest increases in mean occupational earnings with weeks worked. A ten percent increase in weeks worked is associated with an increased in mean occupational earnings by less than one percent in the OLS analyses (Table 5 and 6). As argued in Section II, access to occupations that are, on average, better paying is primarily on the basis of pre-labor market skills, such as educational attainment, rather than on the basis of post-schooling characteristics, such as labor market experience and weeks worked. ${ }^{10}$

There are modest increases in mean occupational earnings or occupational status with years in the US, but only when English skills are not held constant. This implies that improved English skills are the vehicle through which immigrants get access to better paying occupations in the post-arrival period.

\footnotetext{
${ }^{10}$ A comparison of Tables 1 and 2 with Tables 5 and 6 reveals that the log of weeks worked is the only variable whose coefficient changes dramatically. The coefficient of the log weeks worked variables goes from about 1.0 in Tables 1 and 2, to about 0.1 in Tables 5 and 6, respectively. This implies that whereas those who worked more weeks per year in 1999 have (approximately) proportionately higher individual earnings in 1999, having worked in more weeks did not have much of an effect on increasing occupational status. To the extent that weeks worked in 1999 reflects long-term average weeks worked, it may imply greater U.S. labor market experience and, hence a higher occupational status. Yet, this effect is modest.
} 
The English proficiency variables are associated with highly significant changes in mean occupational earnings for the foreign born, ranging from 3 percent to 24 percent differences in mean occupational earnings, and more modest changes in mean occupational earnings - of between 2 and 3 percent - among the native born. These estimated effects are attenuated versions of the effects reported in analyzes of individual earnings. The comparison with the typical study of individual earnings for the foreign born (see Table 2) implies that over one-half of the gain in earnings associated with the acquisition of English skills comes about through inter-occupational mobility. Clearly, knowing the links between language and other human capital skills and the occupation of employment is important to understanding immigrant labor market outcomes. This highlights the importance of research on the determinants of destination language proficiency among immigrants.

\section{B. Quantile Regression Analysis}

The analyzes for the occupational attainment model were repeated using quantile regression (see Buchinsky, 1998) in order to quantify the impact of the explanatory variables across the distribution of occupational attainment scores. The results (not reported here for space reasons but available upon request) show that the effect of educational attainment is relatively small among workers in low-status occupations. Moreover, the effect of education increases with decile of the distribution for the foreign born, but changes little beyond the fifth decile for the native born. Analyzes of the effects of education across the distribution of individual earnings (Chiswick, Le and Miller, 2006) have shown that the payoff to education increases with the decile of the earnings distribution, although the increases in the payoff to educational attainment tend to taper off in the higher deciles. Hence the pattern of effects of educational attainment in the study of occupational status is an attenuated version of the pattern reported in the earnings function literature. This might be expected, given the focus on an occupational average earnings as the dependent variable rather than on an individual measure as in the study of earnings.

The effects of English proficiency on occupational status for the foreign born are similar to that described above for educational attainment, with the effects at the first 
decile being only around one-half the size of the effects across the middle and top end of the distribution of occupational status scores. Among the native born, however, the opposite pattern is observed: the earnings penalty associated with limited English skills is larger at the bottom of the occupational status distribution than it is at the top of the distribution.

Labor market experience has a very minor impact on the occupational status of the native born regardless of the point on the occupational status distribution where this is examined. In comparison, among the foreign born, labor market experience acquired in the country of origin has a negative impact on occupation status which, with the exception of the $9^{\text {th }}$ decile, becomes more pronounced the higher the decile of the occupational status distribution? This relationship is displayed in Figure 1.

Figure 1

Payoffs to Pre-Immigration Experience by Decile, Adult Foreign Born Males in the US

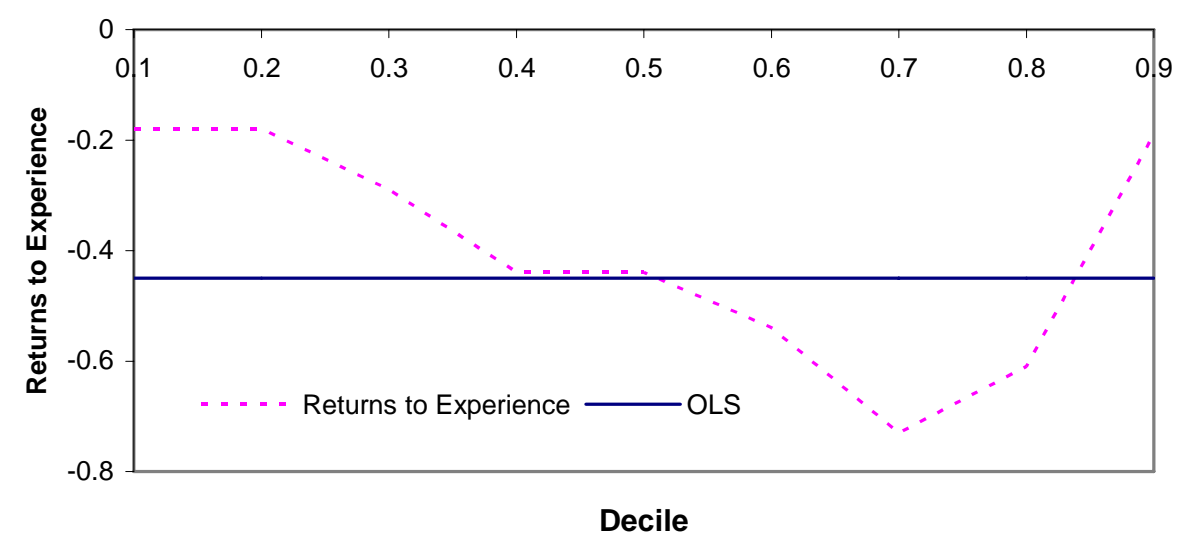

Source: Appendix B, Table B.2.

It is clear from Figure 1 that the adverse consequences of pre-immigration experience for post-arrival occupational status, argued above to be associated with the less-than-perfect international transferability of human capital skills, is of far greater importance among those who enter, on average, high-paying occupations than it is for those who enter low-paying occupations. As low-paying occupations will presumably be 
characterised by low levels of human capital skills, there is less to lose in the migration and hence this result is intuitively reasonable.

Years since migration have a very strong and consistent influence on occupational attainment across the first one-half of the occupational status distribution, but a more modest, and variable, effect across the top half of the occupational status distribution. Chiswick, Le and Miller (2006) also report that the increases in individual earnings with duration of residence are greater in the lower deciles of the (individual) earnings distribution than they are in the upper deciles of the earnings distribution. They attribute this to the so-called importance of initial conditions phenomenon: that the greatest postarrival gains in relative earnings are recorded by the immigrants with relatively low earnings at arrival as they are making greater destination-specific investments in human capital (see Duleep and Regets (1996)(1997)).

\section{CONCLUSION}

This study investigates the role that occupation has in determining the earnings of immigrants and the native born. Occupations can be viewed as providing a link between individuals' attributes and their earnings, and hence the inclusion of variables for occupation in the conventional earnings function is expected to offer fruitful insights. Indeed, the strength of the findings justifies an examination of the determinants of occupational attainment.

The empirical analyzes are based on the 2000 US Census, 1 percent Public Use Microdata Sample. This contains information on 509 specific occupational categories within 23 major occupational groups. The analysis is limited to males aged 25 to 64 years.

The estimation of earnings functions with and without controls for occupation shows that: (i) about one-half of the increase in earnings associated with formal education occurs through entrance into higher-paying occupations for both the native born and the foreign born; (ii) labor market experience among the native born does not appear to be associated with upward occupational mobility; (iii) the increase in the payoff to preimmigration experience among the foreign born following standardization for occupation suggests that the impact of the less-than-perfect international transferability of 
immigrants' human capital results in them being channelled into relatively low-paying occupations; and (iv) immigrants' earnings growth in the post-arrival period occurs largely through intra-occupation earnings mobility.

Two models of occupational attainment were employed, namely an occupational attainment model estimated using Ordinary Least Squares with mean occupational earnings used as the measure of earnings (for around 500 specific occupations), and an ordered probit model where occupational categories were ranked by mean occupational earnings for 23 major occupational groups. Findings from these models further reinforced the empirical results from the comparison of the conventional earnings model and models incorporating occupation control variables. In particular, the estimates of the models of occupation attainment show that immigrants with foreign labor market experience tend to be channelled into lower-paying occupations.

Quantile regressions were estimated to quantify the impact of the explanatory variables across the occupational status distribution. The results from these regressions showed that the negative impact of foreign labor market experience on occupational status was relatively more intense in the upper half of the occupational status distribution. This accords well with the hypothesis regarding the less-than-perfect international transferability of human capital skills.

Knowing the occupation a person works in helps understand their relative earnings. Among immigrants in particular, this knowledge helps us better understand the earnings penalties associated with the less-than-perfect international transferability of human capital skills. 


\section{REFERENCES}

Australian Bureau of Statistics, (1983). Census '81 - Occupation, (Order No. 2148.0), Canberra, AGPS.

Brown, Randall S., Moon, Marilyn and Zoloth, Barbara S., (1980a). "Incorporating Occupational Attainment in Studies of Male-Female Earnings Differentials", Journal of Human Resources, Vol. 15, pp. 3-28.

Brown, Randall S., Moon, Marilyn and Zoloth, Barbara S., (1980b). “Occupational Attainment and Segregation by Sex”, Industrial and Labor Relations Review, Vol. 33, pp. 506-17.

Buchinsky, Moshe, (1998). "Recent Advances in Quantile Regression Models: A Practical Guideline for Empirical Research”, Journal of Human Resources, Vol. 33, No. 1, pp. 88-126.

Chiswick, Barry R. and Miller, Paul W., (1998). The Economic Cost to Native-born Americans of Limited English Language Proficiency, report prepared for the Centre for Equal Opportunity, August 1998: available at www.ceousa.org/earnings.html (Date accessed: 16 November, 2006)

Chiswick, Barry R., Le, Anh T. and Miller, Paul W., (2006). "How Immigrants Fare Across the Earnings Distribution: International Analyzes", IZA Discussion Paper No. 2405.

Duleep, Harriett O. and Regets, Mark C. (1996). "The Elusive Concept of Immigrant Quality: Evidence from 1970-1990”, Discussion Paper PRIP-UI-41, Program for Research on Immigration Policy, Urban Institute, Washington, DC.

Duleep, Harriett O. and Regets, Mark C. (1997). "Measuring Immigrant Wage Growth Using Matched CPS Files”, Demography, Vol. 34, No. 2, pp. 239-249.

Evans, Mariah D.R., (1987). "Language Skill, Language Usage and Opportunity: Immigrants in the Australian Labour Market”, Sociology, Vol. 21, No. 2, pp. 253274.

Evans, Mariah D.R. and Kelley, Jonathan, (1986). "Immigrants' Work: Equality and Discrimination in the Australian Labour Market”, The Australian and New Zealand Journal of Sociology, Vol. 22, No. 2, pp. 187-207.

Groshen, Erica L., (1991). "Sources of Intra-Industry Wage Dispersion: How Much Do Employers Matter?”, The Quarterly Journal of Economics, Vol. 106, No. 3, pp. 869-884.

Jones, F. Lancaster, (1989). "Occupational Prestige in Australia: A New Scale”, Australian and New Zealand Journal of Sociology, Vol. 25, No. 2, pp. 187-199. 
Kidd, Michael P. and Shannon, Michael, (1996). "Does Occupational Aggregation Matter in Determining the Size of the Gender Wage Gap?”, Industrial and Labor Relations Review, Vol. 49, No. 2, pp. 317-329.

Leigh, Duane E., (1976). “Occupational Advancement in the Late 1960s: An Indirect Test of the Dual Labor Market Hypothesis”, Journal of Human Resources, Vol. 11, pp. 155-171.

McKelvey, Richard D. and Zavoina, William, (1975). "A Statistical Model for the Analysis of Ordinal Level Dependent Variable”, Journal of Mathematical Sociology, Vol. 4, pp. 103-120.

Miller, Paul W. (1987). “The Wage Effect of the Occupational Segregation of Women in Britain”, The Economic Journal, Vol. 97, No. 388, pp. 885-896.

Miller, Paul W. and Volker, Paul A., (1985). "On the Determination of Occupational Attainment and Mobility”, Vol. 20, No. 2, pp. 197-213.

Mincer, Jacob, (1979). “A Comment on Sex Discrimination”, in C.B. Lloyd, E. S. Andrews and C. L. Gilroy (eds), Woman in the Labour Market, Columbia University Press, New York and Guildford, Surrey.

Nickell, Stephen, (1982). “The Determinants of Occupational Success in Britain”, Review of Economic Studies, Vol. 49, pp. 43-53.

Polachek, Solomon W., (1981). “Occupational Self-Selection: A Human Capital Approach to Sex Differences in Occupational Structure”, Review of Economics and Statistics, Vol. 63, pp. 60-69.

Schmidt, Peter and Strauss, Robert P., (1975), "The Prediction of Occupation using Multiple Logit Models”, International Economic Review, Vol. 15, pp. 471-485.

Sloane, Peter J., (1985). "Discrimination in the Labour Market”, in D. Carline, C.A. Pissarides, W. Siebert and J. Sloane (eds) Surveys in Labour Economics, Longman Group Limited, Essex, England. 


\section{APPENDIX A \\ DESCRIPTION OF VARIABLES}

The variables used in the statistical analyzes are defined below. Mnemonic names are also listed where relevant.

Data Source: 2000 United States Census of Population, 1 percent Public Use Microdata Sample.

Definition of Population: Native-born and foreign-born men aged twenty-five to sixtyfour. Only residents of the 50 States and the District of Columbia are considered.

\section{Dependent Variables:}

Individual Earnings: The natural logarithm of wage and salary and self-employment income. Responses of less than 100 are set to 100 .

Mean Occupational Earnings: This is the mean of the natural logarithm of earnings in the person's birthplace group (native born or foreign born) in the specific occupation in which he is employed.

\section{Explanatory Variables:}

Educational Attainment (EDUC): This variable records the total years of full-time equivalent education. It has been constructed from the Census data on educational attainment by assigning the following values to the Census categories: completed less than fifth grade (2 years); completed fifth or sixth grade (5.5); completed seventh or eighth grade (7.5); completed ninth grade (9); completed tenth grade (10); completed 11th grade (11); completed 12th grade or high school (12); attended college for less than one year (12.5); attended college for more than one year or completed college (14); Bachelor's degree (16); Master's degree (17.5); Professional degree (18.5); Doctorate (20).

Labor Market Experience (EXP): This is a measure of potential labor market experience, computed as AGE - Years of Education - 6.

Weeks Worked (WEEKS): The number of weeks the individual worked in 1999 is entered into the specification in natural logarithmic form.

Years Since Migration (YSM). This is computed from the year the foreign born person came to the United States to stay.

English Language Fluency: Dichotomous variables are used to capture proficiency levels among both the native born and immigrants. These distinguish individuals who speak a language other than English in the home and who speak English either: (i) "Very Well”; (ii) "Well”; (iii) "Not Well”; and (iv) "Not at All”. The benchmark group is those 
who speak only English at home. For the native born, the final two categories are combined into a single "Not Well/Not at All” category.

Race (BLACK): This is a dichotomous variable, set to one if the individual is Black, and set to zero for all other racial groups.

Marital Status (MARRIED): This is a dichotomous variable that distinguishes individuals who are married, spouse present (equal to 1 ) from all other marital states.

Location: The two location variables record residence of a Metropolitan Areas or of the Southern States (SOUTH). The states included in the latter are: Alabama, Arkansas, Delaware, District of Columbia, Florida, Georgia, Kentucky, Louisiana, Maryland, Mississippi, Missouri, North Carolina, Oklahoma, South Carolina, Tennessee, Texas, Virginia, West Virginia.

Veteran (VETERAN): This is a dichotomous variable, set to one if the individual is veteran, and set to zero otherwise. 
APPENDIX B

Table B.1

Estimates of Quantile Regression for Mean Occupational Income, 25-64 Year Old Native Born Males, 1999

\begin{tabular}{|c|c|c|c|c|c|c|c|c|c|c|}
\hline Variable & OLS & 0.1 & 0.2 & 0.3 & 0.4 & 0.5 & 0.6 & 0.7 & 0.8 & 0.9 \\
\hline Constant & $\begin{array}{c}8.759 \\
(1347.98)\end{array}$ & $\begin{array}{c}8.312 \\
(610.55)\end{array}$ & $\begin{array}{c}8.472 \\
(726.15)\end{array}$ & $\begin{array}{c}8.573 \\
(800.06)\end{array}$ & $\begin{array}{c}8.613 \\
(877.21)\end{array}$ & $\begin{array}{c}8.658 \\
(872.80)\end{array}$ & $\begin{array}{c}8.761 \\
(931.10)\end{array}$ & $\begin{array}{c}8.866 \\
(957.05)\end{array}$ & $\begin{array}{c}9.012 \\
(821.50)\end{array}$ & $\begin{array}{c}9.308 \\
(822.60)\end{array}$ \\
\hline $\begin{array}{l}\text { Educational } \\
\text { Attainment }\end{array}$ & $\begin{array}{c}0.083 \\
(382.53)\end{array}$ & $\begin{array}{c}0.075 \\
(140.58)\end{array}$ & $\begin{array}{c}0.077 \\
(237.42)\end{array}$ & $\begin{array}{c}0.079 \\
(243.85)\end{array}$ & $\begin{array}{c}0.086 \\
(242.41)\end{array}$ & $\begin{array}{c}0.091 \\
(227.64)\end{array}$ & $\begin{array}{c}0.091 \\
(294.22)\end{array}$ & $\begin{array}{c}0.093 \\
(266.58)\end{array}$ & $\begin{array}{c}0.093 \\
(245.40)\end{array}$ & $\begin{array}{c}0.087 \\
(437.18)\end{array}$ \\
\hline $\begin{array}{l}\text { Experience/100 } \\
\text { (EXPER) }\end{array}$ & $\begin{array}{l}0.051 \\
(2.42)\end{array}$ & $\begin{array}{l}0.340 \\
(8.31)\end{array}$ & $\begin{array}{l}0.201 \\
(5.96)\end{array}$ & $\begin{array}{l}0.114 \\
(4.17)\end{array}$ & $\begin{array}{l}0.052 \\
(1.86)\end{array}$ & $\begin{array}{l}0.007 \\
(0.24)\end{array}$ & $\begin{array}{l}-0.066 \\
(2.29)\end{array}$ & $\begin{array}{l}-0.074 \\
(3.12)\end{array}$ & $\begin{array}{l}-0.083 \\
(2.40)\end{array}$ & $\begin{array}{l}-0.285 \\
(10.44)\end{array}$ \\
\hline $\begin{array}{l}\text { EXPER } \\
\text { Squared/1000 }\end{array}$ & $\begin{array}{l}0.020 \\
(4.64)\end{array}$ & $\begin{array}{l}-0.076 \\
(8.64)\end{array}$ & $\begin{array}{l}-0.037 \\
(5.32)\end{array}$ & $\begin{array}{l}-0.012 \\
(2.12)\end{array}$ & $\begin{array}{l}0.013 \\
(2.13)\end{array}$ & $\begin{array}{l}0.033 \\
(5.27)\end{array}$ & $\begin{array}{l}0.054 \\
(9.05)\end{array}$ & $\begin{array}{c}0.066 \\
(13.72)\end{array}$ & $\begin{array}{c}0.078 \\
(11.29)\end{array}$ & $\begin{array}{c}0.123 \\
(20.08)\end{array}$ \\
\hline $\begin{array}{l}\text { Log Weeks } \\
\text { Worked }\end{array}$ & $\begin{array}{c}0.088 \\
(67.71)\end{array}$ & $\begin{array}{c}0.101 \\
(40.48)\end{array}$ & $\begin{array}{c}0.103 \\
(41.08)\end{array}$ & $\begin{array}{c}0.106 \\
(47.13)\end{array}$ & $\begin{array}{c}0.099 \\
(53.25)\end{array}$ & $\begin{array}{c}0.093 \\
(48.34)\end{array}$ & $\begin{array}{c}0.088 \\
(49.07)\end{array}$ & $\begin{array}{c}0.082 \\
(50.13)\end{array}$ & $\begin{array}{c}0.072 \\
(35.88)\end{array}$ & $\begin{array}{c}0.064 \\
(31.98)\end{array}$ \\
\hline Married & $\begin{array}{c}0.102 \\
(89.31)\end{array}$ & $\begin{array}{c}0.138 \\
(69.10)\end{array}$ & $\begin{array}{c}0.134 \\
(72.93)\end{array}$ & $\begin{array}{c}0.117 \\
(78.41)\end{array}$ & $\begin{array}{c}0.097 \\
(62.49)\end{array}$ & $\begin{array}{c}0.102 \\
(71.61)\end{array}$ & $\begin{array}{c}0.098 \\
(72.63)\end{array}$ & $\begin{array}{c}0.086 \\
(54.06)\end{array}$ & $\begin{array}{c}0.075 \\
(40.04)\end{array}$ & $\begin{array}{c}0.059 \\
(43.67)\end{array}$ \\
\hline South & $\begin{array}{c}0.026 \\
(23.61)\end{array}$ & $\begin{array}{c}0.036 \\
(18.03)\end{array}$ & $\begin{array}{c}0.033 \\
(16.43)\end{array}$ & $\begin{array}{c}0.026 \\
(17.69)\end{array}$ & $\begin{array}{c}0.029 \\
(19.24)\end{array}$ & $\begin{array}{c}0.029 \\
(19.57)\end{array}$ & $\begin{array}{c}0.026 \\
(18.83)\end{array}$ & $\begin{array}{c}0.022 \\
(14.75)\end{array}$ & $\begin{array}{c}0.018 \\
(10.22)\end{array}$ & $\begin{array}{l}0.009 \\
(6.51)\end{array}$ \\
\hline $\begin{array}{l}\text { Metropolitan } \\
\text { Area }\end{array}$ & $\begin{array}{c}0.065 \\
(24.53)\end{array}$ & $\begin{array}{l}0.052 \\
(9.49)\end{array}$ & $\begin{array}{c}0.046 \\
(10.30)\end{array}$ & $\begin{array}{c}0.048 \\
(11.41)\end{array}$ & $\begin{array}{c}0.047 \\
(15.09)\end{array}$ & $\begin{array}{c}0.055 \\
(16.40)\end{array}$ & $\begin{array}{c}0.062 \\
(15.71)\end{array}$ & $\begin{array}{c}0.062 \\
(17.80)\end{array}$ & $\begin{array}{c}0.065 \\
(16.83)\end{array}$ & $\begin{array}{c}0.066 \\
(14.50)\end{array}$ \\
\hline Veteran & $\begin{array}{l}-0.009 \\
(7.33)\end{array}$ & $\begin{array}{l}0.004 \\
(1.94)\end{array}$ & $\begin{array}{l}0.004 \\
(2.01)\end{array}$ & $\begin{array}{l}0.004 \\
(2.50)\end{array}$ & $\begin{array}{l}-0.000 \\
(0.21)\end{array}$ & $\begin{array}{l}-0.006 \\
(3.55)\end{array}$ & $\begin{array}{l}-0.009 \\
(6.26)\end{array}$ & $\begin{array}{l}-0.015 \\
(9.49)\end{array}$ & $\begin{array}{c}-0.023 \\
(12.97)\end{array}$ & $\begin{array}{c}-0.028 \\
(13.03)\end{array}$ \\
\hline Blacks & $\begin{array}{l}-0.116 \\
(65.86)\end{array}$ & $\begin{array}{l}-0.094 \\
(26.24)\end{array}$ & $\begin{array}{l}-0.119 \\
(34.23)\end{array}$ & $\begin{array}{l}-0.129 \\
(52.22)\end{array}$ & $\begin{array}{l}-0.115 \\
(49.84)\end{array}$ & $\begin{array}{l}-0.122 \\
(51.61)\end{array}$ & $\begin{array}{l}-0.127 \\
(54.30)\end{array}$ & $\begin{array}{l}-0.125 \\
(46.95)\end{array}$ & $\begin{array}{l}-0.114 \\
(39.70)\end{array}$ & $\begin{array}{l}-0.117 \\
(38.08)\end{array}$ \\
\hline $\begin{array}{l}\text { English Very } \\
\text { Well }\end{array}$ & $\begin{array}{l}-0.023 \\
(9.59)\end{array}$ & $\begin{array}{l}-0.036 \\
(8.83)\end{array}$ & $\begin{array}{l}-0.035 \\
(9.58)\end{array}$ & $\begin{array}{l}-0.031 \\
(7.66)\end{array}$ & $\begin{array}{l}-0.030 \\
(9.80)\end{array}$ & $\begin{array}{l}-0.029 \\
(7.86)\end{array}$ & $\begin{array}{l}-0.024 \\
(6.93)\end{array}$ & $\begin{array}{l}-0.017 \\
(4.25)\end{array}$ & $\begin{array}{l}-0.010 \\
(2.54)\end{array}$ & $\begin{array}{l}-0.001 \\
(0.18)\end{array}$ \\
\hline English Well & $\begin{array}{l}-0.030 \\
(5.05)\end{array}$ & $\begin{array}{l}-0.046 \\
(4.16)\end{array}$ & $\begin{array}{l}-0.048 \\
(3.88)\end{array}$ & $\begin{array}{r}-0.048 \\
(4.37)\end{array}$ & $\begin{array}{l}-0.028 \\
(3.39)\end{array}$ & $\begin{array}{l}-0.026 \\
(3.44)\end{array}$ & $\begin{array}{c}-0.023 \\
(2.47)\end{array}$ & $\begin{array}{l}-0.018 \\
(2.10)\end{array}$ & $\begin{array}{c}-0.008 \\
(0.77)\end{array}$ & $\begin{array}{l}-0.014 \\
(1.07)\end{array}$ \\
\hline $\begin{array}{l}\text { English Not } \\
\text { Well/Not at All }\end{array}$ & $\begin{array}{l}0.015 \\
(1.82)\end{array}$ & $\begin{array}{l}-0.018 \\
(1.10)\end{array}$ & $\begin{array}{l}-0.017 \\
(1.24)\end{array}$ & $\begin{array}{l}-0.008 \\
(0.65)\end{array}$ & $\begin{array}{l}-0.007 \\
(0.59)\end{array}$ & $\begin{array}{l}0.003 \\
(0.22)\end{array}$ & $\begin{array}{l}0.018 \\
(1.42)\end{array}$ & $\begin{array}{l}0.043 \\
(2.67)\end{array}$ & $\begin{array}{l}0.047 \\
(3.54)\end{array}$ & $\begin{array}{l}0.047 \\
(2.58)\end{array}$ \\
\hline
\end{tabular}

Notes: 't' statistics in parentheses; Results based on sample of 533,906.

Source: 2000 US Census 1\% PUMS. 
Table B.2

Estimates of Quantile Regression for Mean Occupational Income, 25-64 Year Old Foreign Born Males, 1999

\begin{tabular}{|c|c|c|c|c|c|c|c|c|c|c|}
\hline Variable & OLS & 0.1 & 0.2 & 0.3 & 0.4 & 0.5 & 0.6 & 0.7 & 0.8 & 0.9 \\
\hline Constant & $\begin{array}{c}9.354 \\
(488.39)\end{array}$ & $\begin{array}{c}9.080 \\
(311.90)\end{array}$ & $\begin{array}{c}9.194 \\
(399.87)\end{array}$ & $\begin{array}{c}9.262 \\
(427.30)\end{array}$ & $\begin{array}{c}9.346 \\
(433.27)\end{array}$ & $\begin{array}{c}9.413 \\
(414.99)\end{array}$ & $\begin{array}{c}9.501 \\
(443.44)\end{array}$ & $\begin{array}{c}9.588 \\
(334.69)\end{array}$ & $\begin{array}{c}9.684 \\
(301.45)\end{array}$ & $\begin{array}{c}9.790 \\
(272.04)\end{array}$ \\
\hline $\begin{array}{l}\text { Educational } \\
\text { Attainment }\end{array}$ & $\begin{array}{c}0.048 \\
(134.06)\end{array}$ & $\begin{array}{c}0.025 \\
(46.75)\end{array}$ & $\begin{array}{c}0.031 \\
(56.76)\end{array}$ & $\begin{array}{c}0.036 \\
(67.76)\end{array}$ & $\begin{array}{c}0.038 \\
(69.47)\end{array}$ & $\begin{array}{c}0.041 \\
(91.05)\end{array}$ & $\begin{array}{c}0.044 \\
(89.44)\end{array}$ & $\begin{array}{c}0.050 \\
(91.22)\end{array}$ & $\begin{array}{c}0.053 \\
(98.01)\end{array}$ & $\begin{array}{c}0.058 \\
(114.26)\end{array}$ \\
\hline $\begin{array}{l}\text { Experience/100 } \\
\text { (EXPER) }\end{array}$ & $\begin{array}{l}-0.820 \\
(15.95)\end{array}$ & $\begin{array}{l}-0.285 \\
(4.41)\end{array}$ & $\begin{array}{l}-0.317 \\
(4.86)\end{array}$ & $\begin{array}{l}-0.514 \\
(7.96)\end{array}$ & $\begin{array}{l}-0.762 \\
(10.80)\end{array}$ & $\begin{array}{l}-0.783 \\
(12.03)\end{array}$ & $\begin{array}{l}-0.970 \\
(12.61)\end{array}$ & $\begin{array}{l}-1.295 \\
(13.43)\end{array}$ & $\begin{array}{l}-1.116 \\
(14.54)\end{array}$ & $\begin{array}{l}-0.522 \\
(6.21)\end{array}$ \\
\hline $\begin{array}{l}\text { EXPER } \\
\text { Squared/1000 }\end{array}$ & $\begin{array}{c}0.185 \\
(19.02)\end{array}$ & $\begin{array}{l}0.054 \\
(4.70)\end{array}$ & $\begin{array}{l}0.067 \\
(5.42)\end{array}$ & $\begin{array}{l}0.111 \\
(9.55)\end{array}$ & $\begin{array}{c}0.161 \\
(12.39)\end{array}$ & $\begin{array}{c}0.173 \\
(15.31)\end{array}$ & $\begin{array}{c}0.213 \\
(15.78)\end{array}$ & $\begin{array}{c}0.283 \\
(17.33)\end{array}$ & $\begin{array}{c}0.255 \\
(18.73)\end{array}$ & $\begin{array}{l}0.167 \\
(9.83)\end{array}$ \\
\hline $\begin{array}{l}\text { Years Since } \\
\text { Migration/100 }\end{array}$ & $\begin{array}{l}0.109 \\
(7.08)\end{array}$ & $\begin{array}{l}0.171 \\
(8.89)\end{array}$ & $\begin{array}{c}0.192 \\
(10.76)\end{array}$ & $\begin{array}{l}0.164 \\
(8.62)\end{array}$ & $\begin{array}{l}0.159 \\
(8.00)\end{array}$ & $\begin{array}{l}0.134 \\
(7.34)\end{array}$ & $\begin{array}{l}0.081 \\
(3.67)\end{array}$ & $\begin{array}{l}-0.002 \\
(0.05)\end{array}$ & $\begin{array}{l}0.024 \\
(1.02)\end{array}$ & $\begin{array}{l}0.092 \\
(3.04)\end{array}$ \\
\hline $\begin{array}{l}\text { Log Weeks } \\
\text { Worked }\end{array}$ & $\begin{array}{c}0.059 \\
(20.14)\end{array}$ & $\begin{array}{c}0.054 \\
(11.65)\end{array}$ & $\begin{array}{c}0.043 \\
(11.13)\end{array}$ & $\begin{array}{c}0.047 \\
(13.34)\end{array}$ & $\begin{array}{c}0.052 \\
(14.65)\end{array}$ & $\begin{array}{c}0.053 \\
(13.57)\end{array}$ & $\begin{array}{c}0.054 \\
(15.63)\end{array}$ & $\begin{array}{c}0.060 \\
(14.19)\end{array}$ & $\begin{array}{c}0.057 \\
(12.62)\end{array}$ & $\begin{array}{l}0.042 \\
(7.36)\end{array}$ \\
\hline Married & $\begin{array}{c}0.079 \\
(26.53)\end{array}$ & $\begin{array}{c}0.053 \\
(13.76)\end{array}$ & $\begin{array}{c}0.059 \\
(18.32)\end{array}$ & $\begin{array}{c}0.072 \\
(21.14)\end{array}$ & $\begin{array}{c}0.081 \\
(20.60)\end{array}$ & $\begin{array}{c}0.083 \\
(22.46)\end{array}$ & $\begin{array}{c}0.087 \\
(21.03)\end{array}$ & $\begin{array}{c}0.097 \\
(19.52)\end{array}$ & $\begin{array}{c}0.083 \\
(17.36)\end{array}$ & $\begin{array}{c}0.062 \\
(10.64)\end{array}$ \\
\hline South & $\begin{array}{l}0.017 \\
(5.51)\end{array}$ & $\begin{array}{l}0.015 \\
(3.98)\end{array}$ & $\begin{array}{l}0.024 \\
(7.09)\end{array}$ & $\begin{array}{l}0.027 \\
(7.63)\end{array}$ & $\begin{array}{l}0.025 \\
(6.99)\end{array}$ & $\begin{array}{l}0.021 \\
(5.52)\end{array}$ & $\begin{array}{l}0.020 \\
(4.67)\end{array}$ & $\begin{array}{l}0.017 \\
(3.06)\end{array}$ & $\begin{array}{l}0.016 \\
(3.24)\end{array}$ & $\begin{array}{l}0.011 \\
(1.94)\end{array}$ \\
\hline $\begin{array}{l}\text { Metropolitan } \\
\text { Area }\end{array}$ & $\begin{array}{l}0.098 \\
(7.10)\end{array}$ & $\begin{array}{l}0.102 \\
(5.11)\end{array}$ & $\begin{array}{l}0.080 \\
(4.86)\end{array}$ & $\begin{array}{l}0.076 \\
(5.21)\end{array}$ & $\begin{array}{l}0.087 \\
(6.29)\end{array}$ & $\begin{array}{l}0.090 \\
(5.78)\end{array}$ & $\begin{array}{l}0.107 \\
(7.33)\end{array}$ & $\begin{array}{l}0.126 \\
(6.13)\end{array}$ & $\begin{array}{l}0.155 \\
(7.03)\end{array}$ & $\begin{array}{l}0.122 \\
(4.26)\end{array}$ \\
\hline Veteran & $\begin{array}{l}-0.035 \\
(5.35)\end{array}$ & $\begin{array}{l}-0.002 \\
(0.23)\end{array}$ & $\begin{array}{l}0.003 \\
(0.32)\end{array}$ & $\begin{array}{l}-0.000 \\
(0.00)\end{array}$ & $\begin{array}{l}-0.007 \\
(0.84)\end{array}$ & $\begin{array}{l}-0.007 \\
(0.72)\end{array}$ & $\begin{array}{l}-0.011 \\
(1.16)\end{array}$ & $\begin{array}{l}-0.049 \\
(4.52)\end{array}$ & $\begin{array}{l}-0.054 \\
(4.37)\end{array}$ & $\begin{array}{l}-0.079 \\
(5.78)\end{array}$ \\
\hline Blacks & $\begin{array}{l}-0.139 \\
(25.85)\end{array}$ & $\begin{array}{l}-0.031 \\
(6.28)\end{array}$ & $\begin{array}{l}-0.077 \\
(15.75)\end{array}$ & $\begin{array}{l}-0.113 \\
(19.00)\end{array}$ & $\begin{array}{l}-0.135 \\
(22.22)\end{array}$ & $\begin{array}{l}-0.148 \\
(20.34)\end{array}$ & $\begin{array}{l}-0.158 \\
(21.41)\end{array}$ & $\begin{array}{l}-0.188 \\
(24.26)\end{array}$ & $\begin{array}{l}-0.204 \\
(22.34)\end{array}$ & $\begin{array}{l}-0.153 \\
(15.27)\end{array}$ \\
\hline $\begin{array}{l}\text { English Very } \\
\text { Well }\end{array}$ & $\begin{array}{l}-0.028 \\
(6.53)\end{array}$ & $\begin{array}{l}-0.017 \\
(3.64)\end{array}$ & $\begin{array}{l}-0.021 \\
(4.24)\end{array}$ & $\begin{array}{l}-0.023 \\
(4.22)\end{array}$ & $\begin{array}{l}-0.031 \\
(5.48)\end{array}$ & $\begin{array}{l}-0.019 \\
(3.29)\end{array}$ & $\begin{array}{l}-0.024 \\
(3.50)\end{array}$ & $\begin{array}{l}-0.027 \\
(3.35)\end{array}$ & $\begin{array}{l}-0.029 \\
(4.57)\end{array}$ & $\begin{array}{l}-0.038 \\
(4.81)\end{array}$ \\
\hline English Well & $\begin{array}{l}-0.172 \\
(36.99)\end{array}$ & $\begin{array}{l}-0.087 \\
(18.07)\end{array}$ & $\begin{array}{l}-0.103 \\
(19.59)\end{array}$ & $\begin{array}{l}-0.134 \\
(24.46)\end{array}$ & $\begin{array}{l}-0.165 \\
(28.44)\end{array}$ & $\begin{array}{l}-0.187 \\
(32.19)\end{array}$ & $\begin{array}{l}-0.205 \\
(32.46)\end{array}$ & $\begin{array}{l}-0.245 \\
(32.49)\end{array}$ & $\begin{array}{l}-0.251 \\
(32.33)\end{array}$ & $\begin{array}{l}-0.186 \\
(20.06)\end{array}$ \\
\hline $\begin{array}{l}\text { English Not } \\
\text { Well }\end{array}$ & $\begin{array}{l}-0.235 \\
(45.18)\end{array}$ & $\begin{array}{l}-0.131 \\
(26.60)\end{array}$ & $\begin{array}{l}-0.140 \\
(24.87)\end{array}$ & $\begin{array}{l}-0.170 \\
(29.62)\end{array}$ & $\begin{array}{l}-0.215 \\
(34.33)\end{array}$ & $\begin{array}{l}-0.245 \\
(43.68)\end{array}$ & $\begin{array}{l}-0.279 \\
(43.41)\end{array}$ & $\begin{array}{l}-0.321 \\
(38.71)\end{array}$ & $\begin{array}{l}-0.353 \\
(40.73)\end{array}$ & $\begin{array}{l}-0.303 \\
(27.88)\end{array}$ \\
\hline $\begin{array}{l}\text { English Not at } \\
\text { All }\end{array}$ & $\begin{array}{l}-0.214 \\
(30.95)\end{array}$ & $\begin{array}{l}-0.147 \\
(19.59)\end{array}$ & $\begin{array}{c}-0.144 \\
(15.99)\end{array}$ & $\begin{array}{l}-0.162 \\
(23.84)\end{array}$ & $\begin{array}{c}0.193 \\
(24.45)\end{array}$ & $\begin{array}{l}-0.217 \\
(28.75)\end{array}$ & $\begin{array}{l}-0.246 \\
(27.67)\end{array}$ & $\begin{array}{l}-0.294 \\
(27.44)\end{array}$ & $\begin{array}{l}-0.330 \\
(28.94)\end{array}$ & $\begin{array}{l}-0.307 \\
(23.31)\end{array}$ \\
\hline
\end{tabular}

Notes: 't' statistics in parentheses; Results based on sample of 84,290.

Source: 2000 US Census 1\% PUMS. 